Innowacje w Pielęgniarstwie i Naukach o Zdrowiu

$2(1) / 2016$

ISSN: 2451-1846

DOI: http://dx.doi.org/10.21784/IwP.2016.007

Dorota Kochman ${ }^{1,2}$, Leokadia Rezmerska ${ }^{1}$, Anna Nowak ${ }^{3}$

1 Instytut Nauk o Zdrowiu, Państwowa Wyższa Szkoła Zawodowa we Włocławku

2 Zakład Pielęgniarstwa, Instytut Nauk o Zdrowiu, Państwowa Wyższa Szkoła Zawodowa

w Płocku,

${ }^{3}$ Wojewódzki Szpital Zespolony w Koninie, NZOZ Słupca

\title{
Wybrane problemy $w$ procesie adaptacji dziecka w wieku 0 - 6 lat do pobytu w szpitalu
}

\section{Selected problems in the adaptation process of children aged 0 - 6 years for the stay in hospital}

\section{Streszczenie}

Wstęp. Dla dziecka w wieku 0 - 6 lat przyjęcie w oddział oraz dalsza hospitalizacja jest bardzo trudnym rodzajem doświadczenia. Łączy się ona z pojawieniem trudności adaptacyjnych do nowego środowiska oraz obcych ludzi. Zadaniem personelu pielęgniarskiego, $\mathrm{w}$ połączeniu $\mathrm{z}$ rodzicami, jest jak największe zniwelowanie powstałego stresu, aby zapewnić dziecku komfort psychiczny i jak najszybsze zakończenie leczenia, bez pozostawiania traumatycznych śladów w psychice dziecka.

Celem pracy była analiza wybranych problemów w procesie adaptacji dziecka do pobytu w szpitalu.

Materiał i metody. W badaniu wykorzystano metodę sondażu diagnostycznego. Zastosowano technikę ankietową, a narzędziem był kwestionariusz 
ankiety. W badaniu udział wzięły dwie grupy: 100 rodziców dzieci w wieku 0-6 lat, które były hospitalizowane oraz personel pielęgniarski pracujący na oddziałach dziecięcych w liczbie 60.

Wyniki. Około 98\% pracowników oraz 27\% rodziców stwierdziło problemy adaptacyjne dzieci przy przyjęciu w oddział. W obu grupach najczęściej występującą trudnością był płacz, odpowiednio 98,31\% i 87\%. 100\% personelu stwierdziło, że obecność rodziców ma pozytywny wpływ na przezwyciężenie trudności adaptacyjnych dziecka. Wykazano brak zależności między poziomem wykształcenia, a postawą personelu pielęgniarskiego wobec rodziców i ich dzieci.

Wnioski. Najczęstszymi trudnościami adaptacyjnymi u hospitalizowanych dzieci są płacz, niepokój i krzyk. Obecność rodziców oraz odpowiednia opieka pielęgniarska może pozytywnie wpływać na przezwyciężenie trudności adaptacyjnych u dziecka. Wykształcenie nie wpływa na postawę personelu wobec dzieci i ich rodziców.

\begin{abstract}
Introduction. For a child of up to 6 years of age, admission to the ward, as well as further hospitalization, is a very difficult kind of experience. It is connected with the appearance of adaptation difficulties to a new environment and strangers. The Nursing staff's task, with cooperation with parents, is the largest possible reduction of stress in children to guarantee the child mental comfort as well as the quickest possible completion of treatment, without leaving traumatic marks in children's psyche.

Aim. The main purpose of the study was to analysis of selected problems in process of child's adaptation to hospitalization period.

Material and Methods. The diagnostic survey method was applied in the research, The survey technique was applied, the survey questionnaire being the tool. Two groups were included in the survey: a hundred parents of the hospitalized children aged $0-6$, and 60 members of the nursing personnel from children's wards.

Results. About $98 \%$ of employees and $27 \%$ of parents noticed adaptation problems of the children at hospital admission. In both groups, cry was the most frequent difficulty that appeared, $98,31 \%$ and $87 \%$ respectively. $100 \%$ of the staff claimed, that parents' presence had a positive influence to overcome child's adaptation difficulties. It has been proved, that there is no rela-
\end{abstract}


tionship between the level of education, and the nursing personnel's attitude towards parents and their children.

Conclusions. The most frequent adaptation difficulties of hospitalized children are: cry, anxiety and scream. The presence of parents and the proper nurse's care, can have a positive effect overcoming child's adaptation problems. Education does not influence staff's attitude towards children and their parents.

Słowa klucze: trudności adaptacyjne, dzieci, pielęgniarstwo

Keywords: adaptation difficulties, children, nursing

\section{Wstęp}

Szpital w odróżnieniu od środowiska domowego jest dla dziecka nowym i całkiem obcym środowiskiem sztucznym. Zaburza poczucie bezpieczeństwa i ogranicza zaspokajanie potrzeb typowych dla dziecka w wieku 0-6 lat. Dziecku choremu trudno jest zrozumieć nową sytuację, w której skazany jest na lęk ból i cierpienie a niekiedy i samotność. Pobyt w szpitalu często kojarzy się małemu pacjentowi z pewnego rodzaju karą, brakiem akceptacji zrozumienia a niekiedy odrzuceniem. Wymaga przyjęcia określonych rygorów, poddania się wielu przykrym zabiegom a często nawet bezwzględnemu leżeniu.

\section{Istota adaptacji w ujęciu psychologicznym}

Adaptację definiuje się jako „dostosowanie zachowania się do zmienności środowiska. Często przez dobre przystosowanie danej osoby rozumie się realistyczne podejście do własnych problemów, równowagę wewnętrzną, właściwą samoocenę, rozwiązywanie konfliktowych sytuacji w sposób możliwie najbardziej realny bez stałego uruchamiania mechanizmów obronnych"[1].

Zdaniem Chwesiuk dziecko podlegające prawidłowym procesom adaptacji, po krótkim okresie ostrożnego wchodzenia w nowe środowisko, zaczyna zachowywać się naturalnie w typowy dla siebie sposób. Potrafi dostosować się do wymogów środowiska, ale jedno- 
cześnie próbuje na miarę swoich możliwości i potrzeb, aktywnie oddziaływać na otaczającą go rzeczywistość. W świetle istniejącej wiedzy pedagogicznej, prawdopodobieństwo zaburzeń procesów przystosowawczych wzrasta w miarę kumulowania się niekorzystnych czynników o charakterze biopsychicznym i socjokulturowym. Należą do nich między innymi: zaburzenia emocjonalne dzieci, zaburzenia struktury rodziny, trudności w szkole, wadliwe postawy rodziców [2].

\section{Przyczyny powstawania problemów adaptacyjnych u dzieci ho- spitalizowanych}

Ograniczenie aktywności ruchowej u dziecka, szpitalna rutyna oraz nuda narusza potrzebę dziecka - nieskrępowanego działania. Szczególnie jej skutków doświadczają dzieci unieruchomione i przewlekle chore. W szpitalu brak jest nie tylko przestrzeni do zabawy, ale i domowego klimatu. Ograniczona aktywność powoduje często złe samopoczucie, apatię brak chęci poruszania się, czasem utratę apetytu, niekontrolowane wybuchy złości i zaburzenia snu. Z powodu braku aktywności myśli dziecka są wypełniane obrazami o treściach lękowych [3].

Jedną z przyczyn powstawania problemów adaptacyjnych u dzieci hospitalizowanych może być już sam fakt wejścia w obce nieznane dziecku miejsce, pełne obcych ludzi, nowych zapachów i nieznanych doświadczeń. Między szóstym a ósmym miesiącem życia dziecko uczy się rozpoznawać osoby mu bliskie i obce. Często właśnie wtedy rodzice mają problem z tą fazą życia u dziecka, ponieważ przejawia się ona strachem przed osobami obcymi. Osoby z najbliższego otoczenia dają mu poczucie bezpieczeństwa, oparcie i pewność siebie. Dotyczy to również dzieci starszych. Przekraczając próg oddziału dziecko traci to poczucie bezpieczeństwa widząc obce twarze. Najczęściej dotyczy to grupy dzieci w wieku 0-6 lat [4].

Dzieciom potrzeba czasu na oswojenie się z nowo zaistniałą sytuacją. To one określają tempo zbliżania się do osób im nieznanych. Jeśli zaś ta osoba (pielęgniarka) zachowuje dystans, wtedy dziecko 
może w pewnym momencie przejąć inicjatywę: szuka kontaktu wzrokowego, uśmiecha się, próbuje zbliżyć się w zabawie lub w wolnej chwili samo domaga się kontaktu fizycznego z personelem [4].

W sytuacji, gdy rodzic zmuszony jest opuścić dziecko i pozostawić je w sali szpitalnej, często zamyka się ono w sobie i kontakt $\mathrm{z}$ nim jest utrudniony. Ale są też dzieci, które na rozstanie z rodzicami reagują histerycznym płaczem, złością a nawet agresją. Buntują się i w ten sposób okazują swoje emocje związane z pozostaniem w obcym miejscu. Zdarza się też, że mały pacjent popada w melancholię a nawet w stany depresyjne. Unika kontaktu z pielęgniarką, personelem a nawet innymi dziećmi, zamyka się w sobie i sam chce sobie poradzić z uczuciem osamotnienia.

Najtrudniejsza jest sytuacja dziecka w wieku od około 18 miesiąca do ok. 3-4 roku życia. Przywiązanie do matki jest wtedy bardzo egoistyczne, dziecko ufa jej bezgranicznie. Dzieci w tym okresie życia najczęściej przejawiają takie trudności adaptacyjne jak apatia, agresja napady złości a także niechęć do zabawy.

Starsze dzieci powyżej 4 roku życia są zdolne do oczekiwania na powrót matki, rozumieją, że rozłąka z nią, mimo iż jest konieczna, będzie krótkotrwała. Dziecko w tym okresie rozwojowym na ogół dość dobrze znosi rozłąkę a kontakty z innymi dziećmi na oddziale rekompensują chwilową nieobecność rodzica. Mogą także przejawiać chwilowe okresy buntu, napady złości albo całkowitą rezygnację.

W przejawiających się trudnościach adaptacyjnych u dzieci hospitalizowanych dostrzega się rolę czynnika psychicznego w całym procesie leczenia jak i po jego zakończeniu. Choroba jest traktowana, jako załamanie czynności adaptacyjnych. Zostaje zaburzona sfera biologiczna, psychologiczna oraz emocjonalna dziecka. Współpraca personelu z opiekunami dziecka jest warunkiem niezbędnym zarówno na etapie rozpoznania choroby jak i w dalszym leczeniu. Kontakt rodziców znacznie ułatwia pielęgniarkom rozpoznanie sytuacji życiowej dziecka i znacznie ułatwia nawiązanie poprawnych relacji $\mathrm{z}$ dzieckiem [4]. 
Celem pracy była analiza wybranych problemów w procesie adaptacji dziecka do pobytu w szpitalu.

\section{Materiał i metody}

W badaniu wykorzystano metodę sondażu diagnostycznego. Zastosowano technikę ankietową, opartą o narzędzie, jakim był kwestionariusz ankiety - dla rodziców dzieci hospitalizowanych składającą się z 16 pytań oraz ankietę dla personelu pielęgniarskiego z oddziałów dziecięcych, składającą się z 14 pytań. Do badania zależności pomiędzy zmiennymi zastosowano test zgodności chi-kwadrat.

Badana grupa składała się z dwóch podgrup: pierwsza to rodzice dzieci hospitalizowanych w wieku 0 - 6 lat, przyjmowanych w oddział dziecięcy w liczbie 100 osób, druga to personel pielęgniarski pracujący na oddziale dziecięcym w liczbie 60 osób.

Personel pielęgniarski to osoby głównie w wieku 41-50 lat, które stanowiły 56,66\% całej grupy badanej. Kolejny pod względem ilości przedział wiekowy, to osoby powyżej 50 roku życia, których było 35\%. Najmniej liczną grupę tworzyły kolejno, respondenci w wieku 31-40 lat - 6,67\% oraz 20-30 lat - 1,67\%. Pod względem wykształcenia, personel pielęgniarski legitymował się głównie wykształceniem średnim (78,33\% całej badanej grupy). Kolejna grupę stanowiły osoby z wykształceniem wyższym (licencjat- 16,67\%), a najmniej liczną grupę stanowili respondenci z tytułem magistra - 5\%. Najwięcej personelu pielęgniarskiego - 50\%, posiadało staż pracy wyższy niż 25 lat. Kolejną grupę stanowiły osoby pracujące od 20 do 25 lat w zawodzie (28,33\%). Najmniej osób biorących udział w badaniu pracowało krócej niż 5 lat, było ich 1,67\%.

\section{Wyniki}

\section{Opinie personelu}

Pierwszą kwestią, jaką zainteresowano się w ramach badań było sprawdzenie skali występowania trudności adaptacyjnych u hospitalizowanych dzieci - 98\% personelu pielęgniarskiego stwierdziło 
występowanie takich trudności. Wszystkie ankietowane pielęgniarki (100\%) potwierdziły, że obecność rodziców wpływa na lepszą adaptację dzieci do warunków szpitalnych. Większość, bo $98 \%$ badanych uważa, że rodzice powinni przebywać ze swoim dzieckiem przez cały okres pobytu w szpitalu, zaś $2 \%$ ankietowanych uważa, że powinni oni być tylko w ciągu dnia.

Większość personelu pielęgniarskiego (95\%) zachęca rodziców do pozostawania razem z dzieckiem podczas jego pobytu w szpitalu, 1,67\% pielęgniarek nie zachęca rodziców, a 3,33\% osób robi to tylko czasami. 0 topografii oddziału oraz o zasadach bhp obowiązujących na oddziale informuje 95\% personelu pielęgniarskiego, a 5\% robi to czasami. Z kolei $15 \%$ pielęgniarek uważa, że rodzice powinni być obecni przy wykonywaniu badań inwazyjnych u dziecka, $37 \%$ jest przeciwnego zdania, natomiast $48 \%$ respondentów twierdzi, że rodzice powinni być obecni tylko przy niektórych badaniach. Natomiast $47 \%$ personelu zawsze nagradza dzieci po wykonanym zabiegu, $51 \%$ czyni to sporadycznie, a $2 \%$ nigdy.

Najczęściej występującymi trudnościami adaptacyjnymi wśród hospitalizowanych dzieci, wskazywanymi przez pielęgniarki były: płacz - 58\%, niepokój - 45\%, krzyk - 29\% oraz napady złości $21 \%$.

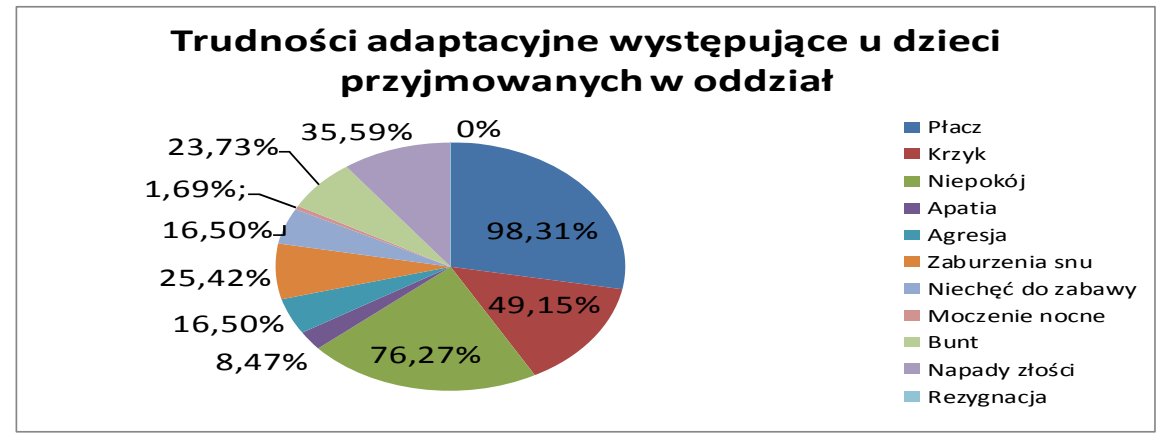

Ryc. 1. Trudności adaptacyjne występujące u dzieci przyjmowanych w oddział w opinii personelu

Źródło: opracowanie własne 
Aby zniwelować trudności adaptacyjne 95\% personelu pielęgniarskiego rozmawia z dziećmi, 37,29\% przytula je, 35,59\% głaszcze, a 30,51\% bierze na ręce.

Wszystkie pielęgniarki (100\%) deklarują znajomość praw dziecka, a $92 \%$ z nich informuje rodziców o tych prawach, zaś $8 \%$ czyni to czasami.

\section{Opinie rodziców}

Znaczący odsetek badanych- 73\% rodziców nie zaobserwowało żadnych trudności adaptacyjnych u dziecka podczas pobytu w szpitalu, natomiast $27 \%$ rodziców takie trudności rozpoznało. $\mathrm{Z}$ grupy rodziców, których dzieci miały trudności adaptacyjne, 89\% stwierdziło, że postawa personelu pielęgniarskiego może mieć wpływ na adaptację dziecka.

Najczęstszymi reakcjami towarzyszącymi przyjęciu dziecka w oddział były: płacz $87 \%$, krzyk 37\% oraz niepokój 38\%.

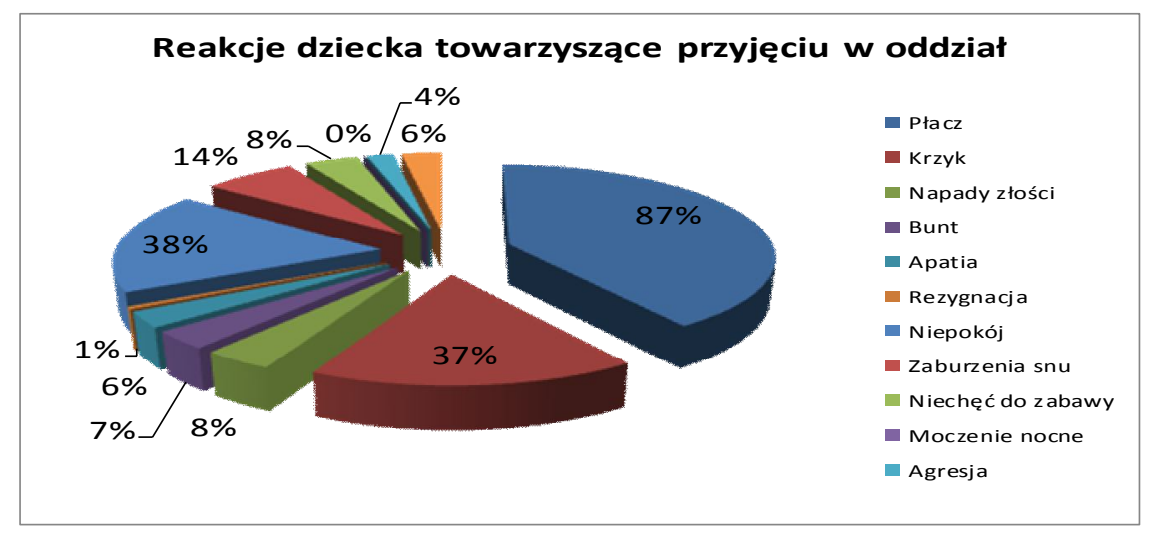

Rycina 2. Najczęstsze reakcje towarzyszące przyjęciu dziecka w oddział w opinii rodziców

Źródło: opracowanie własne

Z badania wynika, że $100 \%$ rodziców było obecnych przy przyjmowaniu ich dzieci w oddział, w tym $96 \%$ z nich było obecnych 
podczas całego pobytu ich dziecka w szpitalu, $4 \%$ przebywało sporadycznie. Żaden z rodziców nie pozostawił swojego dziecka samego. O możliwości pobytu z dzieckiem w szpitalu podczas jego leczenia zostało poinformowanych $92 \%$ ankietowanych, $6 \%$ rodziców podało, że nie otrzymało takiej informacji, a $2 \%$ wskazało, że czasami tak czyniono.

O topografii oddziału i zasadach, jakie tutaj panują poinformowanych przez personel pielęgniarski było 79\% rodziców, 21\% nie było zapoznane z nimi. Większość respondentów (85\%) przebywało wraz z dziećmi podczas badań inwazyjnych, $8 \%$ było nieobecnych, a 7\% uczestniczyło tylko przy niektórych badaniach. Według badanych $40 \%$ dzieci miało zapewniony dostęp do bawialni, 29\% do świetlicy, $19 \%$ do telewizji, a 33\% nie miało lub nie mogło korzystać z tego rodzaju miejsc.

Jeśli chodzi o sposoby nawiązywania kontaktu z dzieckiem to $\mathrm{w}$ opinii $84 \%$ rodziców pielęgniarki czyniły to poprzez rozmowę, w ocenie $42 \%$ badanych poprzez głaskanie, a 15\% respondentów wskazało, że nosiły dzieci na rękach. Zdaniem większości badanych $(60 \%)$ pielęgniarki nagradzały dzieci po wykonaniu badania, $31 \%$ twierdziło, że tego nie czyniły, a w opinii $9 \%$ - nagradzało sporadycznie.

Jeśli chodzi o zachowania wobec dzieci nieakceptowane przez rodziców najczęściej wymieniano: 6\% badanych- niedelikatność, 4\% badanych - zawstydzanie dziecka, a 2\% respondentów straszenie zastrzykami. W opinii 88\% rodziców personel pielęgniarski nie wykonywał żadnych nieprawidłowych czynności wymienionych powyżej. Większość rodziców (52\%) określiło stosunek pielęgniarek wobec dziecka jako życzliwy, 44\% jako bardzo życzliwy, a 4\% jako obojętny. Zdecydowana większość rodziców (80\%) stwierdziła, że ich dziecko miało zapewnione poczucie intymności, godności osobistej oraz bezpieczeństwa, $19 \%$ badanych nie miało zdania na ten temat, a $1 \%$ ankietowanych uznał, że nie zapewniono tego dziecku. Poinfor- 
mowanych przez personel pielęgniarski o prawach dziecka było $52 \%$ rodziców, a 79\% z nich z nich zadeklarowało znajomość praw.

Badając zależności między wykształceniem personelu pielęgniarskiego, a jego zachowaniem i postawą wobec dzieci i ich rodziców przeprowadzono test zgodności chi-kwadrat, którego wyniki są następujące:

a. $\chi^{2}=9,39 ; \quad \chi^{2} 005 ; 4=9,488 ; \quad \chi^{2}<\chi^{2} 0,05 ; 4=>$ dane są niezależne, tzn. wykształcenie pielęgniarek nie miało istotnego wpływu na postawę prezentowaną wobec rodziców towarzyszących dzieciom podczas wykonywania badań inwazyjnych,

b. $\chi^{2}=1,369 ; \chi^{2} 0,05 ; 2=5,991 ; \chi^{2}<\chi^{2} 0,05 ; 2=>$ dane są niezależne, tzn. wykształcenie pielęgniarek nie miało istotnego wpływu na sposób nagradzania dzieci po zabiegu,

c. $\chi^{2}=4,474 ; \chi^{2} 0,05 ; 6=12,592 ; \chi^{2}<\chi^{2} 0,05 ; 6=>$ dane są niezależne, tzn. wykształcenie pielęgniarek nie miało istotnego wpływu na rodzaj czynności niwelujących trudności adaptacyjne u dzieci.

\section{Dyskusja}

Badaniem zostały objęte dwie grupy ankietowanych. Pierwsza z nich to grupa 100 rodziców dzieci w wieku 0-6 lat, przyjmowanych w odział dziecięcy. Drugą badaną grupę stanowiło 60 pielęgniarek, pracujących w dwóch szpitalach w oddziałach, w których hospitalizowane są dzieci.

Warto zauważyć, że grupa pielęgniarek charakteryzuje się niskim odsetkiem osób z wyższym wykształceniem, natomiast posiada bardzo duże doświadczenie ze względu na staż pracy w zawodzie. Badana grupa dobrze odzwierciedla sytuację w całej korporacji zawodowej pielęgniarek, gdzie średnia wieku wynosi 48,43 lata, blisko $35 \%$ personelu znajduje się między 40 - 50 rokiem życia, a ponad $30 \%$ między 51-60 rokiem życia [5,6].

Bliskość dziecka i rodziców stanowi podłoże każdej terapii, która powinna tworzyć w dziecku przekonanie o konieczności zwalczania choroby. Personel pielęgniarski powinien dołożyć wszelkich 
starań, aby oddział szpitalny stał się przyjaznym środowiskiem zarówno dla dzieci, jak i ich rodziców. Dzieci wymagają szczególnej troski i ochrony przed cierpieniem fizycznym oraz psychicznym. Pobyt w szpitalu może być bardziej dotkliwy niż przebyta choroba i jej leczenie, a skutki silnego urazu psychicznego mogą pozostać na lata lub całe życie. W celu zminimalizowania stresu szpitalnego wszyscy pracownicy medyczni muszą bezwzględnie przestrzegać praw i zaspokajać potrzeby chorego dziecka.

Zdecydowana większość pielęgniarek (98,33\%) biorących udział w badaniu stwierdziło, że u przyjmowanych w oddział dzieci występowały trudności adaptacyjne. Tylko 1,67\% respondentów nie zauważyło takich problemów. Z kolei w badanej grupie rodziców, tylko $27 \%$ stwierdziło pojawienie się trudności adaptacyjnych u swoich dzieci, a 73\% nie zaobserwowały takiego zjawiska. Wyniki uzyskane $\mathrm{z}$ ankiet pracowniczych potwierdzają dotychczasowe badania, w których wykazano, że u większości dzieci występują trudności adaptacyjne przy przyjęciu $\mathrm{w}$ oddział. $\mathrm{W}$ badaniu przeprowadzonym przez Kumaczek, trudności adaptacyjne dotyczyły 81,7\% dzieci [7]. Znacząca różnica w odpowiedziach rodziców może wynikać z niedostatecznego zrozumienia, czym są trudności adaptacyjne dziecka i jak je rozpoznać. Na powyższy wynik mógł też wpływać brak obiektywizmu i chłodnej oceny zachowania dziecka, z którym rodzice mają silne więzi emocjonalne. Tym samym odsetek rodziców, jaki zauważył problemy własnego dziecka jest znacząco niższy, w porównaniu z oceną personelu pielęgniarskiego.

Kolejnym problemem, który należy przeanalizować jest zagadnienie dotyczące najczęstszych reakcji towarzyszących dziecku, które zostaje przyjęte w oddział. W przypadku obu badanych grup, odpowiedzi dotyczące tego pytania były podobne. Zarówno pielęgniarki jak i rodzice w swoich odpowiedziach stwierdzili, że najczęściej występującą reakcją dziecka na przyjęcie do szpitala jest płacz. Wskazało taką odpowiedź 98,31\% pielęgniarek oraz 87\% rodziców. Na drugim miejscu w obie grupy respondentów podały niepokój, któ- 
ry zauważyło $76,27 \%$ pielęgniarek i $38 \%$ rodziców. Trzecia z kolei reakcja dziecka, wskazana przez ankietowanych to krzyk. Potwierdziło ją 49,15\% pielęgniarek oraz 37\% rodziców. Wskazane przez badanych najczęściej występujące reakcje dziecka na pobyt w szpitalu mają swoje oparcie także w literaturze. Niepokój wraz lękiem oraz zwiększona płaczliwość to główne przejawy trudności adaptacyjne u dzieci stwierdzone w badaniu Kumaczek [7].

Następny ważny problem poruszony w badaniu to wpływ rodziców na proces adaptacji dziecka do warunków szpitalnych. Pielęgniarki jednomyślnie (100\% badanych) potwierdziły pozytywnie wpływu obecności rodziców na adaptacje ich dzieci podczas pobytu w szpitalu. Wszyscy rodzice w badanej grupie (100\%)byli obecni przy przyjęciu dziecka w oddział, a 96\% rodziców towarzyszyli dziecku przez cały okres pobytu dziecka w szpitalu. Tylko 4\% respondentów stwierdziło, że przebywało z dzieckiem sporadycznie. Wyniki te dowodzą, że zarówno personel pielęgniarski, jak i rodzice dostrzegają pozytywne skutki przebywania dziecka ze swoimi rodzicami podczas leczenia szpitalnego. Dodatkowe wnioski płynące $\mathrm{z}$ badania potwierdzają to stwierdzenie. Większość personelu pielęgniarskiego (98,33\%) uważa, że rodzice powinni być ze swoim dzieckiem podczas całego pobytu w szpitalu. Pielęgniarki (95\%) zachęcają rodziców do takiej decyzji, zapoznają ich z topografią oraz zasadami panującymi w oddziale. Wyniki te mają potwierdzenie w opiniach rodziców, z których większość (92\%) wskazała, że personel informował ich o możliwości pozostania razem z dzieckiem w oddziale, a 79\% badanych poznał oddział. Rodzice i pielęgniarki zauważyli także pozytywne strony obecności najbliższych przy dziecku podczas niektórych zabiegów inwazyjnych, takich jak, pobieranie krwi, założenie wenflonu. Zdaniem 15\% pielęgniarek rodzice powinni towarzyszyć dziecku przy takich czynnościach, 48,33\% respondentów uważa, że może to mieć to miejsce czasami, a $36,67 \%$ badanych stwierdziło, że nie ich obecność nie jest konieczna. Większość rodziców (85\%) potwierdziła, że umożliwiono im pozostanie $\mathrm{z}$ dzieckiem przy zabiegach, $7 \%$ bada- 
nych wskazała, że nie zawsze, a 8\% podało, że nigdy nie mieli takiej możliwości. Odsetek pielęgniarek twierdzących, że rodzice nie powinni być obecni przy zabiegach może wynikać z różnego rodzaju procedur przeprowadzanych na oddziałach. Potwierdzają to wyniki badań z literatury, gdzie stwierdzono niechęć personelu pielęgniarskiego do pozostawania rodziców z dzieckiem w szpitalu i do przebywania ich podczas przeprowadzania zabiegów inwazyjnych [7]. W aktualnych badaniach większość pielęgniarek (83,3\%)była zdania, że rodzice mają decydujący wpływ na zmniejszenie trudności adaptacyjnych dziecka. Warto w tym miejscu dodać, że rodzice mają zagwarantowane prawo do pozostania ze swym dzieckiem w szpitalu [8].

Drugą jakże ważną grupą, która może mieć wpływ na proces adaptacji dziecka do warunków szpitalnych jest personel pielęgniarski. Tylko 27\% rodziców zauważyło trudności adaptacyjne u swoich dzieci. Niemniej jednak większość badanych (88,89\%) stwierdziło, że postawa personelu pielęgniarskiego ma wpływ na proces adaptacji dziecka. Przeciwnego zdania było 11,11\% ankietowanych. Jednocześnie 44\% rodziców oceniło postawę pielęgniarek wobec dziecka jako bardzo życzliwy, 52\% osób jako życzliwy, a tylko 4\% respondentów jako obojętny. Większość rodziców (89\%) nie stwierdziło nieprawidłowego traktowania ich dziecka przez personel pielęgniarski. Tylko 6\% badanych zauważyło brak delikatności pielęgniarek w postępowaniu, $4 \%$ osób podało zawstydzenie a $2 \%$ respondentów straszenie zastrzykami dziecka. Nagradzanie dziecka przez personel pielęgniarski po zabiegu stwierdziło $60 \%$ rodziców. Natomiast $46,67 \%$ pielęgniarek potwierdziło, że nagradza dzieci, $51,66 \%$ z nich czyni to sporadycznie. Według rodziców, najczęściej występującą formą nawiązywania kontaktu pielęgniarki $\mathrm{z}$ dzieckiem była rozmowa $(84 \%$ osób), następnie głaskanie (42\% respondentów) oraz noszenie na rękach (15\%osób). Wyniki te pokrywają się częściowo z odpowiedziami personelu pielęgniarskiego. Większość pielęgniarek (95\%) na wskazało rozmowę, jako czynność wykonywaną w celu niwelowania trudności adaptacyjnych dziecka. Na drugim miejscu, w przeciwień- 
stwie do odpowiedzi rodziców podały one przytulanie $(37,29 \%$ osób)a 35,59\% respondentów wskazywało na głaskanie. Wyniki badań dowodzą, że pielęgniarki zdają sobie sprawę, że ich zachowanie i postawa wobec dzieci ma bardzo duży wpływ na adaptację do hospitalizacji i przebieg jego leczenia. Empatyczne podejście personelu pielęgniarskiego wpływało pozytywnie na proces adaptacji dziecka do warunków szpitalnych.

Przeprowadzana badania wskazują, że pacjenci i ich rodzice wymagają od personelu pielęgniarskiego, nie tylko zdolności manualnych, ale także zrozumienia, wsparcia w trudnych chwilach i życzliwości. Pielęgniarki powinny traktować małego pacjenta, jako partnera w terapii i zachęcać do udziału w leczeniu. Ważna jest również właściwa komunikacja między personelem, a pacjentem skutkująca jego pozytywnym nastawieniem do terapii. Informowanie musi być dostosowane do rozwoju psychicznego dziecka.

Istotne wyniki badań dotyczą znajomości praw dziecka oraz informowaniu o jego prawach. Wszystkie pielęgniarki (100\%) potwierdziły znajomość praw dziecka. Wśród rodziców ich znajomość zadeklarowało $79 \%$ ankietowanych. Większość pielęgniarek $(91,67 \%)$ wskazała, że informowała rodziców o prawach dziecka, a 8,33\% czyniła to czasami. Jednak tylko 48\% rodziców uznało, że było informowanych o prawach dziecka $52 \%$ badanych, że nie otrzymało takiej informacji. Według badań przeprowadzonym w Centrum Zdrowia Dziecka 40\% rodziców zna niektóre prawa dziecka, a 60\% nie umie wymienić żadnego z nich [8]. Wyniki uzyskane w aktualnych badaniach może sugerować albo rzeczywisty wysoki poziom wiedzy na ten temat, albo tak jak w przypadku personelu pielęgniarskiego, często brak odwagi do przyznania się do braku wiedzy o prawach dziecka.

W dzisiejszych czasach $\mathrm{w}$ kształceniu pielęgniarek kładzie bardzo duży nacisk na specjalistyczną wiedzę z zakresu obsługi sprzętu, stosowania leków, wdrażania procedur oraz prowadzenia dokumentacji, co stanowi nieodłączne elementy codziennej pracy 
w systemie ochrony zdrowia. Zapomina się o „umiejętnościach miękkich" takich jak komunikacja personelu z pacjentem, umiejętność empatycznego podejścia, dbanie o potrzeby duchowe i psychospołeczne chorych. Szczególnie przydatne są one w pracy z dziećmi. Często się zdarza, że wysokie umiejętności manualne, profesjonalne przygotowanie do wykonywania zawodu nie idą $\mathrm{w}$ parze $\mathrm{z}$ umiejętnościami społecznymi pracowników. W aktualnych badaniach stwierdzono brak istotnej zależności pomiędzy poziomem wykształcenia pielęgniarek a prezentowaną postawą wobec dzieci $(p>0,05)$. Podobne stanowisko prezentują Tałaj i Suchorzewska, którzy stwierdzili brak zależności między postawą personelu pielęgniarskiego, a poziomem wykształcenia, stażem pracy oraz indywidualnym wyborem miejsca pracy [9].

\section{Wnioski}

1.Hospitalizowane dzieci przejawiają trudności adaptacyjne do hospitalizacji, wyrażające się najczęściej w postaci płaczu, niepokoju i krzyku.

2.Właściwa opieka pielęgniarska i postawa rodziców wpływa pozytywnie na proces adaptacji dziecka i skraca jego pobyt w szpitalu.

3.Poziom wykształcenia personelu pielęgniarskiego nie ma istotnego wpływu na jego postawę wobec rodziców i ich hospitalizowanych dzieci.

\section{Zalecenia dla praktyki pielęgniarskiej}

Dziecko w okresie rozwojowym musi mieć zapewnione podstawowe potrzeby psychiczne takie, jak więź emocjonalna z rodzicami, miłość, aktywność ruchowa i poznawcza, poczucie bezpieczeństwa. Dziecko hospitalizowane narażone jest na silnie negatywne emocje, które bardzo obciążają psychikę, niekorzystnie wpływają na jego dalszy rozwój i proces leczenia. Podczas pobytu w szpitalu dziecko niezbędne jest, aby zaufało ono pielęgniarce i czuło się rozumiane. Pielęgniarka powinna uczynić wszystko, aby zmniejszyć małemu pa- 
cjentowi jego cierpienie, lęk a niekiedy i samotność. Chore dziecko musi wyraźnie czuć, że jest akceptowane, otoczone troską i przyjaźnią.

\section{Bibliografia/Bibliography:}

1. Jolly J. Inna strona pediatrii. PZWL, Warszawa 1987: 123 -167.

2. Chwesiuk G. Program socjoterapeutyczny dla uczniów klas pierwszych z trudnościami adaptacyjnymi. W: Sawicka K. (red.), Socjoterapia. Centrum Metodyczne Pomocy Psychologiczno-Pedagogicznej MEN, Warszawa 1998;30.

3. Sunderland M. Mądrzy rodzice. Świat Książki, Warszawa 2008

4. Wosińska W. Psychologia życia społecznego. GWP, Sopot 2004

5. ICN. Pielęgniarki są siłą na rzecz zmian. Efektywna opieka i racjonalne koszty. International Council of Nurses, Genewa 2015.

6. Raport Naczelnej Rady Pielęgniarek i Położnych. Zabezpieczenie społeczeństwa polskiego $\mathrm{w}$ świadczenia pielęgniarek i położnych. NIPiP, Warszawa 2015 http://www.nipip.pl/dn. 18.06.2016.

7. Kumaczek M. Rola i zadania pielęgniarki w procesie adaptacji dziecka do hospitalizacji. W: Bielawska J. (red.), Aspekty pracy pielęgniarki w opiece nad dziećmi. Acta Scholae Superioris Medicinae Legnicensis., 2008;3: 15 - 23.

8. Jakubik M., Kierys A., Bednarek A. Udział pielęgniarki w adaptacji dziecka do warunków szpitalnych. Problemy Pielęgniarstwa. 2011;19(4):545-550.

9. Tałaj A., Suchorzewska J. Postawy pielęgniarek i położnych wobec osób chorych i cierpiących $\mathrm{w}$ aspekcie obowiązujących norm prawnych i moralnych. Problemy Pielęgniarstwa. 2007;(15),1: 32-38. 
